\title{
The Rise of the Stampatore Camerale: Printers and Power in Early Sixteenth-Century Rome
}

\author{
Paolo Sachet
}

More than any other early modern power, the sixteenth-century Catholic Church is generally identified with a strict, if not reactionary policy towards printing. As part of its struggle against the Reformation, the papacy developed a vast and centralised system of ecclesiastical censorship. While it failed to be as universal as originally envisaged, it had serious ramifications on the culture of Catholic countries, beginning with Italy. An ever-growing number of studies is devoted to this subject, benefiting from the opening of the archive of the Roman Inquisition in 1998 and from the ground-breaking critical edition of the Indexes of Forbidden Books. ${ }^{1}$ By contrast, almost all of the Church's attempts to harness printing as a means of communication in support of its own cause have been largely overlooked. This observation is especially true for the very heart of Catholicism, the city of Rome. In the capital of the Papal States, however, cardinals and popes did employ local publishers to print an array of scholarly books to challenge Protestantism mostly in the patristic and historiographical fields. As I have illustrated elsewhere, these innovative attempts took place long before the establishment of the Typographia Vaticana in $1587 .^{2}$

1 To cite only the most relevant contributions, see Gigliola Fragnito, La Bibbia al rogo: la censura ecclesiastica e i volgarizzamenti della Scrittura (1471-1605) (Bologna: Il Mulino, 1997), as well as her Proibito capire: la Chiesa e il volgare nella prima età moderna (Bologna: Il Mulino, 2005); Vittorio Frajese, Nascita dell'Indice: la censura ecclesiastica dal Rinascimento alla Controriforma (Brescia: Morcelliana, 2006); Peter Godman, The Saint as Censor: Robert Bellarmine between Inquisition and Index (Leiden/Boston: Brill, 20oo); Ugo Rozzo, La letteratura italiana negli Indici del Cinquecento (Udine: Forum, 2005). For the broader picture, see María José Vega, Julian Weiss and Cesc Esteve (eds.), Reading and Censorship in Early Modern Europe (Conference Proceeding, Barcelona, 11-13 December 2007) (Bellaterra: Universitat Autònoma de Barcelona, 2010); Sandro Landi, Stampa, censura e opinione pubblica in età moderna (Bologna: Il Mulino, 2011); and Hubert Wolf, Index: der Vatikan und die verbotenen Bücher (Munich: Beck, 2006). I wish to express my gratitude to Claudia Daniotti, Stephen Parkin and the editors of this volumes for their insightful suggestions and to David Speranzi for his help in tracing two rare bulls in the Biblioteca Nazionale Centrale in Florence.

2 See Paolo Sachet, 'A Humanist Printer Moves from Venice to Rome: The Curial Patronage of Paolo Manuzio', in Cristina Dondi etc. (eds.), La stampa romana nella Città dei Papi e in Europa (Vatican City: Biblioteca Apostolica Vaticana, 2016), pp. 217-233; Paolo Sachet, 'La 
This paper aims to shed light on another little-investigated aspect of the use of movable type by the Roman Curia in the late Renaissance, by focussing on the publication of ephemera rather than erudite books. Revisiting a well-established historiographical topos, it will examine the early days of the Apostolic Chamber's printer (stampatore camerale), a new figure entrusted with disseminating official documentation. According to conventional wisdom, a stream of Apostolic printers starting with the Silbers in the 1510s and continuing with Francesco Calvo and the Blado family have been identified. This assumption, based on no evidence and dated literature, has been uncritically reverberated by distinguished scholars of Roman Renaissance printing, including Francesco Barberi and Emerenziana Vaccaro. ${ }^{3}$

A closer look at sources provides a very different picture. On the one hand, I will question the accepted reconstruction of the events by showing the risks in building a firm chronology upon uncertain dates, such as those related to official broadsheets. On the other, I will analyse some key published and unpublished archival acts and draw attention, for the first time, on printers' networks and the internal politics of the papal Curia. Such wide-ranging documentation will show how the innovative office of stampatore camerale resulted from a considerably slower process than previously thought, shedding light on the intermediary role of high offices in the relation between printers and rulers. Dynamics were marked by sheer competition and political patronage, in which the heads of the Apostolic Chancery and Chamber played a crucial part. In fact, the formalisation of the stampatore camerale took place as late as the spring of 1550, when Julius III eventually acknowledged Blado's services and assigned the publication of official material by means of a privilege, granted only to him. In doing so, the pope paved the way to the integration of the stampatore camerale into the papal administration, turning printing into an affair of state.

Chiesa davanti ai Padri: Erasmo, gli umanisti riformati e la patristica cattolica romana tra Rinascimento e Controriforma', Rivista di storia e letteratura religiosa, 54:2 (2018), pp. 389419; and my book Publishing for the Popes: The Roman Curia and the Use of Printing (1527-1555) (Leiden and Boston: Brill, 2020), where I discuss in details the earlier, scattered bibliographical studies on the topic and anticipate part of this contribution.

3 Emerenziana Vaccaro, 'Documenti e precisazioni su Antonio Blado ed eredi', Bollettino dell'Istituto di patologia del libro, 9 (1950), pp. 48-85, at pp. 51, 57. Francesco Barberi, 'Blado, Antonio', in Dizionario biografico degli Italiani (DBI), X, 1968, pp. 753-757, at p. 753; his 'Calvo, Francesco Giulio', DBI, XVII, 1974, pp. 38-41, at p. 39; and his essays collected and republished in Tipografi romani del Cinquecento: Guillery, Ginnasio Mediceo, Calvo, Dorico, Cartolari (Florence: Olschki, 1983), pp. 19-20 and, less assertively, at p. 84 . 


\section{Early Printers, 'Red Tape' and the Papacy}

With the arrival of Sweynheym and Pannartz and other German typographers, Rome and its surroundings were the cradle of Italian printing in the 1460s and 7os. ${ }^{4}$ However, support for and interaction with this new mode of communication came mainly from a few high-ranking curial prelates, such as the bishops Giovanni Andrea Bussi and Rodrigo Sánchez de Arévalo and the Cardinals Bessarion, Cusa, Torquemada and Todeschini Piccolomini, rather than from the papacy as an institution. ${ }^{5}$ Nor should the occasional granting of privileges to protect some works from piracy be seen as a well-thought political, cultural or religious policy on the part of the Curia; as was the case within other privilege-granting bodies across early modern Europe, the whole process usually started with a plea from the individual printer or the author of a specific work, not from the upper ranks. ${ }^{6}$ At the end of the fifteenth century and beginning of the sixteenth, papal interest in printing generally leaned towards regulation rather than exploitation, as the threatening implications of an almost unlimited and unmediated access to knowledge started to become

4 For a general overview of the development of priting in Rome, see Francesco Barberi, 'Librai e stampatori nella Roma dei Papi', in Francesco Barberi, Per una storia del libro: profili, note, ricerche (Rome: Bulzoni, 1981), pp. 197-235, at pp. 197-211 and Gian Ludovico Masetti Zannini, Stampatori e librai a Roma nella seconda metà del Cinquecento. Documenti inediti (Rome: Fratelli Palombi, 1980). For the years before 1527, see in particular Concetta Bianca etc. (eds.), Scrittura, biblioteche e stampa a Roma nel Quattrocento: aspetti e problemi: atti del seminario, 1-2 giugno 1979 (Vatican City: Scuola Vaticana di paleografia, diplomatica e archivistica, 1980); Massimo Miglio (ed.), Scrittura, biblioteche e stampa a Roma nel Quattrocento: atti del II seminario, 6-8 maggio 1982 (Vatican City: Scuola Vaticana di paleografia, diplomatica e archivistica, 1983) and Massimo Miglio, Saggi di stampa: tipografi e cultura a Roma nel Quattrocento, ed. by Anna Modigliani (Rome: Roma nel Rinascimento, 2002); Paola Farenga (ed.), Editori e edizioni a Roma nel Rinascimento (Rome: Roma nel Rinascimento, 2005); Cristina Dondi etc. (eds.), La stampa romana.

5 See the recent overview provided by Concetta Bianca, 'Le strade della "sancta ars": la stampa e la curia a Roma nel XV secolo', in Dondi et al. (eds.), La stampa romana, pp. 1-8.

6 See Maria Grazia Blasio, "Cum gratia et privilegio": programmi editoriali e politica pontificia Roma (1487-1527) (Rome: Roma nel Rinascimento, 1988); and for a broader perspective, based on different sources, see Jane C. Ginsburg, 'Proto-Property in Literary and Artistic Works: Sixteenth-Century Papal Printing Privileges', The Columbia Journal of Law \& the Arts, 36 (2013), pp. 345-458. On privileges elsewhere in Europe, see Edwige Keller-Rahbé, Henriette Pommier and Daniel Régnier-Roux (eds.), Privilèges de librairie en France et en Europe - XVI ${ }_{-}$ $X V I I^{e}$ siècles (Paris: Classiques Garnier, 2017), including the Venetian case analysed by Angela Nuovo, 'Naissance et système des privilèges à Venise du XVe au XVI ${ }^{\mathrm{e}}$ siècle', pp. 331-347, which can be integrated with Sabrina Minuzzi (ed.), The Invention of the Author: The Privilegio di Stampa in Renaissance Venice (Venice: Marsilio, 2017). See also Erika Squassina and Andrea Ottone (eds.), Privilegi librari nell'Italia del Rinascimento (Milan: Franco Angeli, 2020). 
apparent for the Church's political and religious authority. The interventions of Innocent VIII in 1487, of Alexander VI in 1501 and of Leo X in 1515 moved in this direction: building a system of preliminary censorship in which printing licenses known as imprimatur were issued by local bishops or, in the Eternal City, by the Master of the Sacred Palace. ${ }^{7}$

It was only in the early sixteenth century that the papacy began to interact with the technology of movable type more and more consistently in order to serve an immediate purpose, i.e., spreading its proclamations more quickly, cheaply and broadly. This bureaucratic use is hardly surprising given the pope's two-fold identity as both a temporal and spiritual authority. Just as his political orders needed to be disseminated throughout his temporal domain, so too, did his religious pronouncements have to reach the faithful throughout his spiritual domain, which was depicted as ostensibly global ('Urbi et orbi'). No other European ruler either enjoyed the benefices or had to shoulder the burdens of a theocracy that produced a comparable quantity of official material. Bulls, briefs, indulgences, motu propri, taxes, laws and bandi, as well as statutes, rules and constitutions for lay guilds and religious orders were constantly promulgated by different authorities, from the pope himself to the various bodies comprising the intricate Roman bureaucratic system, such as the Apostolic Chamber, the Chancery, the Datary, the tribunals of Penitentiary, Sacra Rota and Signatura as well as the Commune of Rome (also known as Popolo Romano). ${ }^{8}$

7 Frajese, Nascita dell'Indice, pp. 15-35, stresses the very limited effect of these first regulations. Nevertheless, they marked an extremely important turn, if one considers the development of the control over printing established in the following decades and centuries by the Catholic and Protestant churches, as well as by European lay rulers; see references in footnote 1 and Mario Infelise, I padroni dei libri: Il controllo sulla stampa nella prima età moderna (Rome/ Bari: Laterza, 2014).

8 For an historical overview of the papal administration, see Fernando de Lasala and Paulius Rabikauskas, Il documento medievale e moderno: panorama storico della diplomatica generale e pontifica[!] (Rome: Pontificia Università Gregoriana and Istituto portoghese di Sant'Antonio, 2003), esp. pp. 222-266. Current bibliographical standards make it difficult to pinpoint the exact amount of printed material produced by the early modern Curia, since authorship is either regarded as anonymous or variously (if not randomly) attributed to 'Catholic Church', the reigning pope or a specific department of the papal bureaucracy. Nevertheless, USTC statistics show how the Stamperia Camerale, the official administrative press established in the early seventeenth century, is by large the most productive firm in the first two centuries of Western printing, with nearly 100 editions averagely issued every year between 1605 and 1650 (https://ustc.ac.uk/results?qo=0,o,1\&qp=1\&qso=11 accessed on $05 / 04 / 2020$ ). See Flavia Bruni, 'In the Name of God: Governance, Public Order and Theocracy in the Broadsheets of the Stamperia Camerale of Rome', in Andrew Pettegree (ed.), Broadsheets: Single-Sheet Publishing in the First Age of Print (Leiden: Brill, 2017), pp. 139-161. 
These texts could normally be fitted onto a single broadsheet, and printed rapidly in large quantities with little effort. These advantages were important, since the area of impact, so to speak, of papal documentation was often extraordinarily vast, requiring remarkably high print-runs. From Rome bulls travelled throughout Europe. It is clear that no single printer in the Eternal City had the wherewithal to supply the entire continent. But here the interests of other European entrepreneurs came to the Church's aid. The universality of this type of ephemeral documents was a very appealing feature for early printers, who were in constant need for opportunities to recoup their investments as quickly as possible. The trade in papal proclamations and other local administrative commissions has correctly been identified as a way of providing printers' business with a steady, regular income and workflow. ${ }^{9}$ It is no coincidence that Gutenberg and other early printers were publishing indulgences as early as the mid-1450s. ${ }^{10}$

The Roman pontiffs were not the first to centralise administrative publications by appointing a single, trusted printer in the capital city to carry out this work. The only two earlier cases are to be found in England and France, while, on the Italian peninsula, this practice only became more established in the second half of the sixteenth century. ${ }^{11}$ For reasons that still require further research, the pioneer in the field was the ruler of a then peripheral area of Europe: Henry VII of England. He granted the title of the King's official printer to William Faques as early as 1504. Two years later, Richard Pynson, a more experienced entrepreneur, managed to obtain the role for himself and developed it systematically, receiving a regular salary. On ascending to the throne in 1509, Henry VIII renewed his reliance on Pynson, who continue to act as the privileged royal printer until his death in 1529 , de facto expanding his monopoly into the production of indulgences and works of state propaganda thanks to the support of Cardinal Wolsey. By February 1530, Thomas Berthelet had taken

Peter Stallybrass, “Little Jobs”: Broadsides and the Printing Revolution', in Sabrina A. Baron, Eric N. Lindquist and Eleanor F. Shevlin (eds.), Agent of Change: Print Culture Studies After Elizabeth L. Eisenstein (Amherst/Boston:University of Massachusetts Press, 2007), pp. 315341. For the methodological challenges posed by conservation problems and the ensuing disproportion of seventeenth-century extant specimens, see Ugo Rozzo, La strage ignorata: i fogli volanti a stampa nell'Italia dei secoli XV e XVI (Udine: Forum, 2008) together with two insightful articles: Andrew Pettegree, 'Broadsheets: Single-Sheet Publishing in the First Age of Print. Typology and Typography', in Pettegree (ed.), Broadsheets, pp. 1-32 and Flavia Bruni, 'Early Modern Broadsheets between Archives and Libraries: Toward a Possible Integration', Pettegree (ed.), Broadsheets, pp. 33-54.

10 E.g., USTC 743954-743955. See Rozzo, La strage ignorata, pp. 11-25.

11 Angela Nuovo, 'Stampa e potere. Sondaggi cinquecenteschi', Bibliologia, 1 (2006), pp. $53^{-85}$. 
over; from then on, the office of the King's (or Queen's) printer never ceased to exist. ${ }^{12}$ The French Kings had also granted similar kindred titles sporadically since 1487, but according to Elizabeth Armstrong their meaning seemed to be related to 'the recognition of an already achieved distinction', with no material benefit resulting from them. Only beginning between 1559 and 1561 did official proclamations began to be entrusted by law to a privileged printer, such as Jean Dallier, Michele de Vascosan and, above all, François Estienne. ${ }^{13}$

In Rome, it appears that a handful of printers, such as Eucharius and Marcellus Silber, Johann Besicken, Giacomo Mazzocchi and Etienne Guillery, controlled the publication of administrative material from the beginning of the sixteenth century onwards. Based on limited surviving documents, we can infer that they shared this profitable sector of the local market in a somewhat haphazard fashion. It is worth noting that most broadsheets do not carry any imprint information. Colophons were probably deemed unnecessary for two reasons. First, the printing location was obviously Rome, and pronouncements already ended with a date, often showing the name of the official who had been tasked with the compilation - the segretario ai brevi for papal briefs, the custos for the Chancery and the notary for the Apostolic Chamber. Secondly, these editions were intended for immediate consumption: within a few days from promulgation they were normally distributed in print and attached on church doors or in other relevant meeting places. Modern attribution to a specific printer relies on the detailed analysis of types and decorative title borders. As Tinto convincingly demonstrated, the two Silbers were responsible for the majority of the extant bulls, bandi etc. which were issued before the Sack of Rome in $1527 .{ }^{14}$ They can be rightfully regarded as the most prominent pub-

12 See Pamela Neville-Sington, 'Press, Politics and Religion', in Lotte Hellinga and Joseph B. Trapp (eds.), The Cambridge History of the Book in Britain, III: 1400-1557 (Cambridge: Cambridge University Press, 1999) pp. 576-6o7, summing up her Ph.D. dissertation, Richard Pynson, King's Printer (1506-1529): Printing and Propaganda in Early Tudor England (London: The Warburg Institute, 1990); for a broader picture see Graham Rees and Maria Wakely, Publishing, Politics and Culture: The King's Printers in the Reign of James I and VI (Oxford: Oxford University Press, 2009); Lotte Hellinga, William Caxton and Early Printing in England (London: The British Library, 2010); Vincent Gillespie and Susan Powell, A Companion to the Early Printed Book in Britain (1476-1558) (Cambridge: Brewer, 2014).

13 Elizabeth Armstrong, Robert Estienne, Royal Printer: An Historical Study of the Elder Stephanus: Revised Edition ([Abingdon]: Sutton Courtenay, 1986), pp.117-118, 155-156, from which the quotation in text is taken, and her Before Copyright: The French Book-Privilege System, 1498-1526 (Cambridge: Cambridge University Press, 199o).

14 Alberto Tinto, Gli annali tipografici di Eucario e Marcello Silber (1501-1527) (Florence: Olschki, 1968). 
lishers of contemporary papal 'red tape', and this prominence was probably due to some special relationship they had established with particular powerful individuals within the Curia.

However, when they placed their imprint on the productions, neither the Silbers nor the other printers made explicit reference to any institutional link whatsoever with the pope or the Apostolic Chamber. This reflects the simple fact that no such official connection yet existed. It would thus be misleading to consider either Eucharius and Marcellus Silber or even Giacomo Mazzocchi as official printers, as, rather surprisingly, many authorities in the field repeatedly did. ${ }^{15}$ The only way in which they can be vaguely regarded as forerunners of the stampatore camerale is that they succeeded in obtaining a commercial primacy over competitors in a relatively open market, though this does not imply that they were officially sanctioned. Between 1505 and 1523, only Mazzocchi and Guillery styled themselves with an official title in the colophons of their publications, but they did so to indicate their (presumably competitive) activity as 'Romanae Academiae bibliopolae', i.e., the chief booksellers to the University of Rome, the Studium Urbis. ${ }^{16}$

\section{Francesco Minizio Calvo: The Rise and Fall of a Humanist Publisher}

By the mid-1520s, the Roman printing scene had drastically shrunk. In this context, the Curia began to formalise a privileged relationship with a single printer. Two northern Italians were able to profit from this new situation: Francesco Minizio Calvo and Antonio Blado. Unlike other promising colleagues, namely Ludovico degli Arrighi and Demetrios Doukas, they both managed to survive the sack in 1527 unscathed and could exploit the lack of serious competitors in the following decade. Contrary to his brother Michele in Venice, Francesco

15 Valentino Romani - in his 'Per lo Stato e per la Chiesa: la tipografia della Reverenda Camera Apostolica e le altre tipografie pontificie (secc. XVI-XVIII)', Il Bibliotecario, (1998), pp. 175-192, at p. 175 and his 'Tipografie papali: la Tipografia Vaticana', in Massimo Ceresa (ed.), Storia della Biblioteca Apostolica Vaticana: II: La Biblioteca Vaticana tra Riforma Cattolica, crescita delle collezioni e nuovo edificio (1535-1590) (Vatican City: Biblioteca Apostolica Vaticana, 2012), pp. 261-279, at p. 265 - is more prudent on the matter, while Masetti Zannini, Stampatori e librai, p. 167 went as far as stating that a 'Stamperia camerale' existed from the very beginning of Blado's printing activity in 1516 .

16 Fernanda Ascarelli, Annalitipografici di Giacomo Mazzocchi (Florence: Sansoni, 1961), esp. nos. 1 and 158, and Francesco Barberi, 'Stefano Guillery e le sue edizioni romane (15061524)', in Barberi, Tipografi romani, pp. 9-55, at pp. 13-14, 16, 20. Evangelista Tosini, a third university bookseller in the early sixteenth century, paid for the publication of Ptolemy's Geography in 1507 and 1508 (USTC 851474 and 851481). 
Tramezzino never opened a print shop in Rome. Instead, he remained a prominent bookseller in the city, while Valerio Dorico, who began as a music publisher, went back to issuing a variety of books as late as 1531-1532. Only six years later, he was able to expand his activity in association with his brother, Luigi. ${ }^{17}$

When compared with his earlier and immediate predecessors, including the learned Giacomo Mazzocchi, Francesco Minizio Calvo's profile as a scholar is outstanding. Probably born in Menaggio (Como), he was a gifted humanist and bookseller in Pavia in 1516. Travelling throughout Europe, he met important members of the European humanist circles such as Alciato, Minuziano, Amaseo, Egnazio, Erasmus, Rhenanus, Amerbach, Froben and Grolier. For a couple of years, he also sympathised with Luther's ideas. In 1520-1521, he settled in Rome, where he relied on the support of Paolo Giovio and Gian Matteo Giberti. At the time these two men were employed in the service of Cardinal Giulio de' Medici, who was the powerful head of the Chancery (vicecancellarius) under his cousin Leo $\mathrm{x}$. Soon Calvo became acquainted with Giulio de' Medici and opened his own print shop in 1523, the same year Giulio de' Medici was elected as Pope Clement VII. Giberti was quickly put in charge of the Datary and emerged as Clement vir's diplomatic mastermind; Calvo benefitted from Giberti's promotion. During this time, he published a dozen comedies including plays by Ariosto, Bibbiena, and Machiavelli - and some classical and humanist literature, such as works by Plutarch, Galen, Erasmus, Politianus and Giovio. ${ }^{18}$ Beginning in January 1524 , he also started to print numerous bulls and pronouncements of the Chancery and the Apostolic Chamber, gradually taking over from Marcellus Silber as the leading printer of this type of material. For a few months, Silber and Calvo both continued to publish the same broadsheets separately, but soon Silber's firm faced an irreversible crisis. ${ }^{19}$

17 See respectively: Alberto Tinto, Annali tipografici dei Tramezzino (Venice/Rome: Istituto per la collaborazione culturale, 1966), esp. pp. XII-XIII; Francesco Barberi, 'I Dorico, tipografi a Roma nel Cinquecento (1526-1572)', in Barberi, Tipografi romani, pp. 99-146 (originally published in 1965), and, briefly, Lorenzo Baldacchini, 'Dorìco, Valerio e Luigi' in Marco Menato, Ennio Sandal and Giuseppina Zappella (eds.), Dizionario dei tipografie degli editori italiani: il Cinquecento, I: A-F (Milan: Editrice bibliografica, 1997), pp. 388-391. On Arrighi and Doukas see the entries in Menato, Sandal and Zappella (eds.), Dizionario dei tipografi e degli editori, pp. 41-45 and 401-403.

18 The detailed catalogue of his output is given in Francesco Barberi, 'Le edizioni romane di Francesco Minizio Calvo', in Miscellanea di scritti di bibliografia ed erudizione in memoria di Luigi Ferrari (Florence: Olschki, 1952), pp. 57-98, at pp. 64-98 (a short-title version can be found his Tipografi romani, pp. 78-97, at pp. 89-97). For Calvo's life, see Barberi's DBI entry mentioned above, with earlier bibliography.

19 Tinto, Gli annali di Eucario e Marcello Silber, nos. 320-33o. See also Barberi, 'Le edizioni di Calvo', p. $5^{8}$ for a few collaborations between the two about 1522, with Calvo still acting as a publisher. 
As a result, Calvo achieved a prominent role in the small world of contemporary Roman printing. He was a learned man with the technical expertise and, most importantly, the right connections with the Roman establishment. In the paratext of Calvo's books, Giberti's name crops up several times as either a dedicatee or a patron, and we know that, in his capacity of probibliotecharius, Giberti made sure Calvo could borrow books from the Vatican Library. ${ }^{20}$ In light of the prelate's later engagement with official printing in his diocese of Verona, these are crucial pieces of evidence. ${ }^{21}$ On the one hand, they confirm his role as the main patron of Calvo's enterprise; on the other, they suggest that it was probably thanks to Giberti that the Curia eventually officially recognised Calvo's primacy. In the final sentences of a papal proclamation written in the Italian vernacular and dated 24 January 1527 , Calvo's name is accompanied by a new title, that of impressore apostolico. ${ }^{22}$ Since no payment to Calvo can be traced in the papal account books, and this is, as far as we know, the first and only occurrence of the title in print, it is probable that the title was more honorific than the indication of a proper office. In a contract of March 1527 , he is mentioned as « calcografus apostolicus », and Alciato addressed him in similar terms in a letter he wrote in September $1530^{.23}$

Not even the vicissitudes of the sack of Rome in 1527 created a significant setback for Calvo and his enterprise. He escaped the Landsknechts' massacre

20 Cf. Giovanni Mercati, 'Su Francesco Calvo da Menaggio primo stampatore e Marco Fabio Calvo da Ravenna primo traduttore del corpo ippocratico in latino', in Mercati, Notizie varie di antica letteratura medica e di bibliografia (Rome: Tipografia poliglotta vaticana, 1917), pp. 47-71, at pp. 52, 56 and Barberi, 'Le edizioni di Calvo', nos. 4, 14, 20, 39-40, 59, 66, 68-69, 86, 93, 120 (probably plus nos. 2, 46, 67 and 128-129).

21 On the two Veronese episcopal presses founded by Giberti from 1529 onwards, see Adriano Prosperi, Tra evangelismo e controriforma: Gian Matteo Giberti (1495-1543) (Rome: Edizioni di Storia e Letteratura, 1969), pp. 217-234; Lorenzo Carpané and Marco Menato, Annali della tipografia veronese del Cinquecento, I (Baden-Baden: Koerner, 1992), pp. 21-23; Cristina Stevanoni, 'Il greco al servizio della riforma cattolica: per uno studio della tipografia di Stefano Nicolini da Sabbio e di G.M. Giberti a Verona (1529-1532), in Nikolaus M. Panayotakis (ed.), Origini della letteratura neogreca: atti del secondo Congresso internazionale 'Neograeca Medii Aevii', Venezia 7-10 novembre 1991, II (Venice: Istituto Ellenico di Studi Bizantini e Postbizantini, 1993), pp. 6o6-632; Cristina Stevanoni, 'La grande stagione dei libri greci', in Ennio Sandal (ed.), Il mestier de le stamperie de i libri: le vicende e i percorsi dei tipografi di Sabbio Chiese tra Cinque e Seicento e l'opera dei Nicolini (Brescia: Grafo, 2002), pp. 83-110, esp. nos. 34 and 35; and Ennio Sandal, 'Scrittura devota ed editoria religiosa nella bottega dei Nicolini da Sabbio', in Commentari dell'Ateneo di Brescia, (2004), pp. 247-277. The last two scholars interpret Giberti's enterprise as an unproblematic part of the so-called 'Catholic reformation', a point of view open to debate.

22 USTC 822964, seemingly lost, and Barberi, 'Le edizioni di Calvo', no. 88.

23 Barberi, 'Le edizioni di Calvo', pp. 6o-62 (drawing kindred conclusions about the difference between Calvo's title and that of stampatore camerale) and Mercati, 'Su Francesco Calvo', pp. 55-56. 
by taking refuge, along with Jean Grolier's son, in the residence of the Spanish bishop Cassador. Six months after the sack his press was again operational, printing a new bull by which Clement viI revoked all the concessions he had granted during his imprisonment. ${ }^{24}$ In contrast to Calvo's activities, the papacy took more time to recover, with the papal court in Orvieto and the actual government of Rome in the hands of a legate, Cardinal Lorenzo Campeggi. From Cesar Grolier's diary we known that the printing of the famous bull In coena Domini was entrusted to Calvo by the legate Cardinal Campeggi. ${ }^{25}$ The power vacuum helped Calvo to strengthen his position as the sole reliable and experienced printer in town, as can be traced in the official publications he still managed to produce at a growing pace, between 1528 and 1529. The conditions to become more than a publisher of administrative broadsheets were increasingly favourable, if only the Curia had been prepared to use the printed word to launch a counterattack on the millenarian, Imperial and Reformed propaganda which was canvassing the pillage as a sign of God's wrath. ${ }^{26}$

Clement VII had more pressing concerns than orchestrating a campaign in print, ostensibly failing to grasp the extent to which negative publicity was damaging his public image both on the Italian peninsula and beyond the Alps. He succeeded in reasserting his political role, making peace with his enemy Emperor Charles v, recovering part of the territories he had lost and even obtaining the return of de' Medici family to Florence. Yet he remained unresponsive to the threats posed by pamphlets like Alfonso de Valdés's renowned Diálogo de las cosas acaecidas en Roma, Diálogo de Mercurio y Carón and Apologia altera refutatoria. ${ }^{27}$ While the dialogues were first printed in Spanish as anonymous editions probably by the Nicolini brothers in Venice between 1529 and 1530, the Apologia was also printed in Basel with a false imprint showing Rome as the place of publication in 1528 . The printer responsible for this

24 USTC 822962.

25 Barberi, 'Le edizioni di Calvo', p. 6o and nos. 98, 101-104, 107.

26 See Ottavia Niccoli, Profeti e popolo nell'Italia del Rinascimento (Rome/Bari: Laterza, 1987), pp. 224-239 and Massimo Firpo, 'Il sacco di Roma del 1527 tra profezia, propaganda politica e riforma religiosa', in Massimo Firpo, Dal sacco di Roma all'Inquisizione. Studi su Juan de Valdés e la Riforma italiana (Alessandria: Edizioni dell'Orso, 1998), pp. 7-6o, at pp. 49-6o. For a broader picture of the phenomenon: André Chastel, Le sac de Rome, 1527: du premier maniérisme à la Contre-Réforme (Paris: Gallimard, 1984) and Ottavia Niccoli, Rinascimento anticlericale: infamia, satira e propaganda in Italia tra Quattro e Cinquecento (Rome/Bari: Laterza, 2005).

Respectively, USTC 34289o, 342889 and 861671. 
wilful degradation of the papal authority was Johann Faber aus Emmich, concealed under the pseudonyms 'Emmeus' and 'Nicetas Pistophilus.' ${ }^{28}$

1530 marked a watershed in Calvo's short career as an officially designated printer. Just after Giberti had been dismissed from his role as Clement viI's chief political advisor, the number of Calvo's commissions from the Curia plummeted. ${ }^{29}$ This further reinforces the hypothesis that Calvo's enterprise and his connections with the Roman establishment depended largely upon Giberti's own fortune in the papal hierarchy. Calvo's last official publication dates from September 1530, though he kept printing other books over the course of the following years. ${ }^{30}$ Even after he had fallen ill with gout in November 1533, he ostensibly reissued Maximilianus Transylvanus's exotic epistolary report on the Moluccas. Significantly, in this last of his Roman editions, he decided to maintain the original dedication to Giberti, who is still addressed as the head of the Datary. ${ }^{31}$

\section{Antonio Blado: The Long Road to Becoming a Stampatore Camerale}

Meanwhile, a new star was rising in the background: Antonio Blado. A printer from Asola (Mantua), Blado had been active in Rome since 1516, developing a profitable business with a strong focus on popular books. His publications included guides to Roman churches and monuments in different languages (Mirabilia Urbis), pasquinades, almanacs and prophecies, devotional, didactic, medical, music and chivalric books, political and religious orations as well as early anti-Protestant pamphlets. ${ }^{32}$ In strong contrast with Calvo, prior to 1530

28 See USTC 612463 and 861671 , referring to the same edition described differently in VD16 and EDIT16: no copy with the Basel imprint has yet been traced.

29 Elena Bonora, Aspettando l'imperatore: principi italiani tra il papa e Carlo V (Turin: Einaudi, 2014) provides the most updated picture of the political context after the Sack of Rome.

$30 \quad$ USTC $8099 \circ 7$.

31 UstC 841639, unknown to Barberi, 'Le edizioni di Calvo'. In respect of the edition carried out ten years earlier, coincidentally in November 1523 , this one is exceedingly rare and shows a wholly reset text from gathering B onwards. Inspected Copy: Oxford, Bodleian Library, Vet. F1 e.42.

32 His output was carefully reconstructed by Giuseppe Fumagalli, Giacomo Belli and Emereziana Vaccaro, Catalogo delle edizioni romane di Antonio Blado asolano ed eredi (1515-1593) (4 vols, Rome: Presso i principali librai, 1891-1961). For his biography, see Barberi, 'Blado, Antonio', together with: Giuseppe Fumagalli, Antonio Blado tipografo romano del sec. XVI (Milan: Hoepli, 1893); Vaccaro, 'Documenti e precisazioni', Marco Menato and Giuliano Tamani, 'Blado, Antonio', in Menato, Sandal and Zappella (eds.), Dizionario dei tipografi, I, pp. 147-149; and Valentina Sestini, 'Blado, Antonio', in Rosa 
he only occasionally ventured into publishing humanist works, preferring to invest in short, cheap books intended for wide circulation - most of which have probably been lost. Papal and curial pronouncements fitted Blado's business model very well. The fact that he printed a good number of them from the mid-1520s shows that Calvo did not enjoy any exclusive rights in their production. ${ }^{33}$ In 1530, the proportion of official publications issued by Calvo and those printed by Blado reversed in favour of the latter. Ultimately, Blado, rather than Calvo, became the printer who was the first appointed stampatore camerale, with a privilege granting him the monopoly for this ephemeral material.

Nevertheless, the process leading to Blado obtaining this position was considerably more problematic than has usually been thought. Since it took some twenty years, it needs to be thoroughly examined in all its complexity. Earlier scholarship tended to emphasize a continuity between the roles held by Calvo and Blado, but such a view is misleading and, more importantly, is not sustained by the evidence. For instance, Barberi suggests that, when Calvo moved to Milan around 1534, he passed his typographical equipment on to Blado, along with the appointment as a 'papal printer'. While the first assumption is entirely correct, as the two printers' use of the same typefaces makes clear, the second is based on no ascertainable grounds at all and seems to contradict what Barberi himself has pointed out elsewhere about the elusive nature of Calvo's title. ${ }^{34}$ Even supposing there was such a transition, it is unlikely that it would have been a smooth one. Blado certainly did not wait for Calvo to leave the city in 1534 and was already in open competition with him four years before that. In August 153o, he started to receive payments from the Apostolic Chamber for printing papal proclamations. ${ }^{35}$

These overlaps and changes seem to mirror the remarkable shift in power taking place in the upper echelons of the Curia in the aftermath of the sack of the city. While Giberti left Rome for Verona, the newly-created Cardinal Ippolito de' Medici, the pope's nephew, immediately rose to prominence and replaced Giberti as one of the main patrons of arts and letters. ${ }^{36}$ Blado was

Marisa Borraccini, etc. (eds.), Dizionario degli editori, tipografi, librai itineranti in Italia tra Quattrocento e Seicento (Pisa/Rome: Fabrizio Serra, 2013), I, pp. 147-152. On Mazzolini, see Michael Tavuzzi, Prierias: The Life and Works of Silvestro Mazzolini da Prierio (1456-1527) (Durham: Duke University Press, 1997).

33 E.g., USTC, 822908, 822924, 822933, 822938, 822970, 836331.

34 Barberi, 'Blado, Antonio', p. 753 and Barberi, 'Calvo, Francesco Giulio', p. 39 with his 'Le edizioni di Calvo', p. 62.

35 Vaccaro, 'Documenti e precisazioni', pp. 57, 73.

36 Guido Rebecchini, "Un altro Lorenzo": Ippolito de' Medici tra Firenze e Roma (1511-1535) (Venice: Marsilio, 2010). On the later development of the cardinale nipote, see Antonio 
directly involved in the academies of Vignaiuoli, Virtuosi and Nuova Poesia, which were held at the cardinal's court and in the house of Giovanni Gaddi, another prominent figure of the Florentine milieu in Rome. It was through Gaddi (and almost certainly thanks to de' Medici) that Blado managed to obtain, on 23 August 1531, the extraordinary ten-year papal privilege to print all Machiavelli's works - his first important commission in terms of learned literary works. ${ }^{37}$ To Blado's advantage, Ippolito de' Medici became head of the Chancery in 1532.

Interestingly, around October 1530 the name 'Platyna' appeared in Blado's colophons, ostensibly making reference to the first perfect of the Vatican library Bartolomeo Sacchi (Platina), who was a close relative of Blado. By inserting this name, Blado may have wanted to emphasise his origins and revive his family network at an opportune moment. Agostino Spinola, a grand-nephew of Sixtus IV from the Riario branch, had been appointed as head of the Apostolic Chamber. His papal ancestor had been a key patron of Sacchi; by invoking his name, it may be that Blado hoped to receive the same support by the newlyappointed Spinola. ${ }^{38}$

Blado continued to benefit after a change in papal leadership in 1534 with the election of Paul III and his connections within the Curia and the Roman cultural milieu were not lost even upon the sudden death of Ippolito de' Medici in August 1535. A large part of de' Medici's entourage started to serve the 15-year-old new Cardinal nephew Alessandro Farnese. Cardinal Farnese

Mennitti Ippolito, Il tramonto della curia nepotista. Papi, nipoti e burocrazia curiale tra XVI e XVII secolo (Rome: Viella, 2008).

37 Only the Discorsi, Historie and Principe were issued: ustc, 839309, 839312-839313. Six months later, Pope Clement vi granted a similar privilege to Bernardo Giunta, who had already started publishing these works in Florence with the consensus of Machiavelli's heirs (cf. ustc, 839296, 839302, 839314). See: Adolf Gerber, Niccolò Machiavelli: Die Handschriften, Ausgaben und Übersetzungen Seiner Werke Im 16. und 17. Jahrhundert (Gotha: Perthes, 1912), passim; Pio Paschini, 'Note alle prime edizioni del Machiavelli', Atti dell'Accademia degli Arcadi, n.s., 6-7 (1930), pp. 67-77; and Roberto Ridolfi, Vita di Niccolò Machiavelli: settima edizione italiana accresciuta e riveduta (Florence: Sansoni, 1978), pp. 514, 531, 598. For what little is known about the two academies, see Michele Maylender, Storia delle Accademie d'Italia (5 vols., Bologna: Cappelli, 1926-1930), IV, p. 86; v, pp. 141, 478-480, as well as Chiara Quaranta, Marcello II Cervini (1501-1555): Riforma della Chiesa, Concilio, Inquisizione (Bologna: il Mulino, 2010), p. 76, nn. 105-107, and Enrico Garavelli, "L'erudita bottega di messer Claudio": nuovi testi per il Reame della Virtù (Roma 1538)', Italique, 16 (2013), pp. 111-154. I consider them as separate circles, following Guido Rebecchini, 'Un altro Lorenzo': Ippolito de' Medici, pp. 216-219.

38 Augusto Campana, 'Antonio Blado e Bartolomeo Platina', in his Scritti. I: ricerche medievali e umanistiche, ed. by Rino Avesani, Michele Feo and Enzo Pruccoli (2 vols., Rome: Edizioni di Storia e Letteratura, 2012), I, pp. 283-293, originally published in 1947. The relevant 1530 edition by Blado is USTC 814183 . 
had immediately 'inherited' most of de' Medici's lucrative benefices and the management of the Apostolic Chancery. Blado's name appears in print for the first time as impressor cameralis (printer of the [Apostolic] Chamber) in a group of three bulls about the Order of Knights of St Peter, the last of which was propagated by Paul III - but not necessarily printed - in December $15355^{39}$ Although this is normally taken as a terminus post quem for Blado's activity as official printer, we should bear in mind that bulls were reissued every now and then and there is no certainty about the precise date of printing. This is a case in point with regard to the pitfall of such a practice. Significantly, shorter versions of Blado's '1535' edition of the three bulls about the Order of Knights of St Peter, comprising only the first two pronouncements originally issued by Leo $\mathrm{X}$ and Clement VII about $15^{21}$ and $15^{26}$, also circulated with the same subscription by Blado. Nevertheless, no one would consider them as early evidence of his official role in the $15^{20 s}{ }^{40}$ The woodcut of Paul III's coat-of-arms with the black fleur-de-lys at sig. $\mathrm{G}^{\mathrm{r}}$ also suggests that the 1535 bull edition was printed later. Blado started to use this image - usually within an elaborate wreath - no earlier than 1543-1544, while his output of the mid-153os often bears the wreathed version with the white fleur-de-lys. ${ }^{41}$ Finally, it is noteworthy that all these documents were reprinted around 1561 , together with a new bull by Pius IV concerning the Knights. On this occasion Blado used the same wording to describe himself as impressor cameralis. ${ }^{42}$

Once we take 'December 1535' off the table, it is necessary to look for another, sounder date as the earliest evidence of Blado's official appointment. Thus, it is essential to follow his steps for a little longer. As early as July 1536, Blado was entrusted with a four-year privilege for the printing of the breviary, which

\footnotetext{
39 USTC 84869 o.

40 USTC $848685^{-848686 .}$

41 In particular, one can compare the bulls related to the ecumenical council between ${ }_{153} 6$ and 1545 . Although they generally have no printing date, the rapidly-changing scenario, which eventually led to the opening of the assembly in Trent, guarantees that such delicate pronouncements were printed and circulated very closely to their date of promulgation and then quickly superseded Cf. USTC $86 \circ 88$ o, 860882-86o884, 860886 with USTC $86 \circ 887-86 \circ 888,86 \circ 891$.

42 Cf. USTC 848693 and 848692 . In all its complexity as a source, Ms 255 in the Biblioteca dell'Archivio di Stato of Rome may provide another pointer to the possibility that all these bulls showing Blado as impressor cameralis were issued long after 1535 . As the original title label reveals, this eighteenth-century manuscript volume appears to be an inventory of the former archive of the Stamperia Camerale. It lists chronologically the official documents produced by the different official presses until 1694 according to their date of promulgation. While most proclamations are recorded as single items, the bulls related to the Order of St Peter are mentioned only once and collectively at f. 32 , under the date 25 August 1561.
} 
had recently been revised and reformed by Cardinal Quiñones. He published the first edition himself, while, together with two partners, he subcontracted the publication of the second edition to the Venetian branch of the Giunta family. ${ }^{43}$ When Cardinal Spinola died in 1537 , luck was again on Blado's side, since the newly-appointed camerlengo was the other grand-son of Paul III, Cardinal Guido Ascanio Sforza di Santa Fiora, who was to remain in power for over 25 years.

From Santa Fiora's appointment on, it was just a matter of time for Blado to see his privileged commercial relationship with the Curia, and the Apostolic Chamber in particular, to be officially recognised and protected by law. Scholars have debated the date when this took place, but Fumagalli is correct in arguing that it could not have happened earlier than $1549 .{ }^{44}$ The second known occurrence of the official title crops up in a bull promulgated in October 1538, but printed with what look like later types employed by Blado and heirs. Shortly afterwards, as we learn from the Chamber's account books, Blado started to receive a regular monthly stipend, precisely in his capacity as 'Camerae Apostolicae impressor/stampator'. 45

Nevertheless, over the course of the following decade he used the title in his own publications inconsistently. In a preface addressed to Cardinal Sforza di Santa Fiora in 1559, Blado recalled that, upon receiving the camerlengo's mandate, he had begun to act as the sole official printer some fifteen years earlier, i.e., $1544 / 45{ }^{46}$ On a closer examination, this assertion sounds too hasty, if not openly misleading, since in the mid-1540s curial documents were still occasionally published by other printers, such as Girolama Cartolari. ${ }^{47}$ In any case, by May 1547, Blado was allowed (or felt confident enough) to sign a

43 John Wickham Legg, The Second Recension of the Quignon Breviary: Following an Edition Printed at Antwerp in 1537 and Collated with Twelve Other Editions (2 vols, London: Henry Bradshaw Society, 1908-1912), and his 'An Agreement in 1536 between Certain Booksellers of Rome and Venice to Bring out the Second Text of the Reformed Breviary of Cardinal Quignon: With Introduction, List of Editions, and Bibliographical Notes', The Library, 13 (1913), pp. 323-348. For the historical context, see also Simon Ditchfield, Liturgy, Sanctity and History in Tridentine Italy: Pietro Maria Campi and the Preservation of the Particular (Cambridge: Cambridge University Press, 1995), pp. 23-27.

44 Fumagalli, Antonio Blado, pp. 6o.

45 USTC 853172. Vaccaro, 'Documenti e precisazioni', pp. 73-74; in the payment order of 24 May 1539, he was also addressed as 'bullarum suae santitatis[sic] stampator' (Rome, Archivio di Stato, Mandati camerali, vol. 871, f. 176r).

46 Fumagalli, Antonio Blado, pp. 38-39. Retrospectively, Blado's heirs successfully went as far as to present him as the official printer since either 1528 or even the reign of Leo $\mathrm{X}$.

47 Barberi 'La tipografia romana di Baldassarre Jr. e Girolama Cartolari (1540-1559)', in Tipografi romani, pp. 147-163 (originally published in 1951), at pp. 154-155. 
full-length book - Ambrogio Fracco's Sacrorum Fastorum libri XII - with the pompous inscription 'S.D.N. Papae et Camerae Apostolicae Typographum.48 In his further step forward to obtain an official role, he likely benefitted from the recent appointment of Cardinal Ranuccio Farnese, another of the pope's grandsons, as head of the Penitentiary, a key department of the Curia which had been in control of the Pucci family for more than 25 years. Getting closer and closer to obtaining the full control over official publications, Blado was able to expand his grip beyond the boundaries of the Eternal City, publishing, at least as far as we know, the statutes of two municipalities located in the environs, such as Sezze and Rieti. ${ }^{49}$

The real turning point took place during the first months of 1550, following Paul III's death and Julius III's election. With a motu proprio signed on 10 March, the new pontiff acknowledged the long-standing service provided by Blado, who was by then about 65-years old, as printer of the Apostolic Chamber and Chancellery ('Camera et Cancelleria impressor') under Clement VII and Paul III. In this capacity, Julius rewarded him with a fixed monthly salary of 4 ducati starting from the day of his own election (7 February 1550), and granted a universal privilege, valid for two years after the publication of all Blado's Latin and vernacular editions, explicitly including broadsheets. A month later, Cardinal Sforza of Santa Fiora transmitted the order to the treasurer of the Apostolic Chamber, who took note in the account book of the new arrangement for Blado's pay. ${ }^{50}$ The role of official printer had finally been created. As a result, only Blado was responsible for and allowed to print all current bulls, pronouncements, bandi, charters, avvisi and regulations. However, he also continued to undertake major publications as a private entrepreneur, while occasionally using his official title in their colophons or title-pages too. The role, which fitted so well into the Church's hierarchy that it soon became as venal as other offices, was passed on to Blado's heirs until 1594 and granted the family business a constant cash flow. The popes were assured that their proclamations and other official material would be issued smoothly and efficiently for a relatively small amount of money (roughly 36 scudi per year).

\footnotetext{
48 USTC 830470.

49 USTC $856127,852558$.

$50 \quad$ Romani, 'Per lo Stato', p. 176 passingly mentioned this crucial document, which is found in Vatican City, Archivio Segreto Vaticano, Cam. Ap., Div. Cam., vol. 161, f. 41r-42r. The privilege was originally envisaged to last for three years, as the correction of 'triennium' in 'biennum' makes clears.
} 


\section{Conclusion}

The emergence of an official printer to the papal administration was a much slower and more problematic process than has been generally assumed. The contacts between a few Rome-based printers and the Curia before the spring of $155^{\circ}$ are largely due to the temporary commercial primacy these printers managed to exert and the network of prelates supporting them. Even the most suited candidate for the position of stampatore camerale, Antonio Blado, took 15 years to attain the longed-for papal appointment, though he was acting as the de facto printer of the Apostolic Chamber. Nevertheless, officiality is not a matter of interpretation, especially not at the time. The formal creation of the role occurred only with Julius III's resolution in $155^{\circ}$ and cannot be anticipated to 1535 on the basis of the alleged earliest appearance of the related title in the imprint of a proclamation made in that year, but likely reprinted later on. Postdating is never without consequence. In this case, it sheds new light on the importance of the pontificates of Paul III and Julius III as well as on the personalities who were interested in helping Blado to achieve prominence, and who progressively centralised administrative publications into his hands. In this respect, Paul III's grandsons emerged as key figures in their capacity as heads of Apostolic Chamber, Chancellery and Penitentiary. These were the departments of the papal administration which benefitted the most from a quick, efficient and economical strategy to disseminate their numerous proclamations in print.

The Roman case illustrates well how the relationship between print and power can be mutually influential. Some particularly enterprising printers aimed to monopolise the market of administrative publications and secure cash flow through permanent commissions; for this, they had to win the support of rulers and ministers. In their turn, early modern suzerains and their officers turned to printers more and more frequently in their attempt to enhance the distribution of their pronouncements aimed to expand their grip on subjects and to increase control over their lands.

Yet the much belated appointment of Blado is also a potent reminder of the power of bureaucracy, especially in courts where a spoils system was significantly hindered by the usually lifelong nature of the most important administrative tasks, as was the case in the Curia. The more complex the government administration was, the longer it would take for a specific printer to turn his position of prominence into an official role, as this entails persuading a larger number of high officials. Exceptional networking skills and continuous adjustments to the change in leadership were essential components of this laborious process. 


\section{Appendix: A Chronological Overview of the Editions Cited}

USTC 743954

Chappe, Paulinus, [Indulgentia for contributions to the war against the Turks, 1454-1455] ([Mainz: Printer of the 42-line Bible [=Johann Gutenberg], 1454-1455]).

USTC 743955

Chappe, Paulinus, [Indulgentia for contributions to the war against the Turks, 1454-1455] ([Mainz: printer of the 31-line indulgence and of the 36-line Bible, 1454-1455]).

USTC 851474

Ptolemy, Geographiae (Rome: Bernardino Vitali for Evangelista Tosini, 1507).

USTC 851481

Ptolemy, Geographiae (Rome: Bernardino Vitali for Evangelista Tosini, 1508).

USTC 836331

Innocent VIII and Alexander VI, Bulle super fundatione officii dominorum collectorum plumbi ([Rome: Antonio Blado, after 1516]).

USTC 848685

Leo X, Bulla erectionis Collegii dominorum militum sancti Petri de Urbe (Rome: Antonio Blado, [1521]).

USTC 822908

Clement viI, Bulla contra homicidas ([Rome: Antonio Blado, 1524]).

\section{USTC 822924}

Clement viI, Bullae duae tramsumptae per R.P.D. episcopum Vigorniensem ([Rome: Antonio Blado, 1524]).

USTC 822933

Clement VII, Bando contra li sudditi soi Duchi, Marchesi, Conti, Baroni et altri Signori ([Rome: Antonio Blado, 1526]).

USTC 848686

Clement VII, Bulla erectionis officii dominorum Militum sancti Petri (Rome: Antonio Blado, [1526]). 
USTC 822938

Clement viI, Bulla in qua Mons Fidei erigitur pro christianae fidei defensione ([Rome: Antonio Blado, 1526]).

USTC 822962

Clement viI, Bulla per quam gratias et expectativas revocat ([Rome: Francesco Minizio Calvo 1527]).

USTC 822964

Clement viI, Clementevescovo servo de'servi di Dio a futura memoria ([Rome: Francesco Minizio Calvo 1527]).

USTC 861671

Valdés, Alfonso de, Apologia (Rome: Emmeus apud Nicetas Pistophilus [i.e. Basel: Johann Faber aus Emmich], 1528).

USTC 822970

Clement viI, Breve super locationibus, pensionibus, \& censibus domorum, vinearum, casalium ([Rome: Antonio Blado, 1529]).

USTC 809907

Clement VII, Regula Cancellarie super extensione consensuum in resignationibus (Rome: [Francesco Minizio Calvo], 1530).

USTC 342889

Valdés, Alfonso de, Dialogo de Mercurio y Caron ([Venice: Giovanni Antonio Nicolini and brothers, 1530]).

USTC 342890

Valdés, Alfonso de, Dialogo en que particularmente se tratan las cosas acaecidas en Roma en año de M.D.XXVII. ([Venice: Giovanni Antonio Nicolini and brothers, 1530]).

USTC 839309

Machiavelli, Niccolò, Discorsi sopra la prima Deca di Tito Livio (Rome: Antonio Blado, 1531).

USTC 839296

Machiavelli, Niccolò, Discorsi sopra la prima Deca di Tito Livio (Florence: Bernardo Giunta, 1531). 
USTC 839313

Machiavelli, Niccolò, Il principe [et alia] (Rome: Antonio Blado, 1531).

USTC 839312

Machiavelli, Niccolò, Historie (Rome: Antonio Blado, 1532).

USTC 839302

Machiavelli, Niccolò, Historie fiorentine (Florence: Bernardo Giunta, 1532).

USTC 839314

Machiavelli, Niccolò, Il principe [et alia] (Florence: Bernardo Giunta, 1532).

USTC 841639

Transylvanus (von Sevenborgen), Maximilianus, Caesaris a secretis epistola, de admirabili \& novissima Hispanorum in orientem navigatione (Rome: Francesco Minizio Calvo, 1533).

USTC 848690

Leo X, Clement VII and Paul III, Bulla erectionis officii dominorum militum sancti Petri (Rome: Antonio Blado [1535]).

USTC $86 \circ 88$ o

Paul III, Bulla indictionis sacrosancti generalis Concilii ([Rome: Antonio Blado, 1536]).

USTC 830470

Fracco, Ambrogio Novidio, Sacrorum fastorum libri XII (Rome: Antonio Blado, 1537).

USTC $86 \circ 882$

Paul III, Bulla indictionis sacrosanctigeneralis Concilii ([Rome: Antonio Blado, 1537]).

USTC $86 \circ 883$

Paul III, Bulla prorogationis sacrosancti generalis Concilii ([Rome: Antonio Blado, 1537]).

USTC 860884

Paul III, Bulla novae prorogationis sacrosancti generalis Concilii ([Rome: Antonio Blado], 1538). 
USTC 853172

Paul III, Bulla super confirmatione facultatum Collegii scriptorum archiuii Rom. Curiae (Rome: Antonio Blado [1538]).

USTC 84668 o and 848691

Paul III, Bulla Collegii militum s. Pauli (Rome: Baldassarre Cartolari, 1541).

USTC $86 \circ 886$

Paul III, Bulla sacri oecumenici Concilii Tridenti celebrandi ([Rome: Antonio Blado], $1542)$.

USTC 860887

Paul III, Bulla declaratoria suspensionis sacrosancti generalis Concilii, et revocationis legatorum ([Rome: Antonio Blado, 1543]).

USTC $86 \circ 888$

Paul III, Bulla sacri oecumenici et generalis Concilii, ad quartam dominicam in quadragesima proxime futura celebrandi, seu prosequendi ([Rome: Antonio Blado, 1544]).

USTC 860891

Paul III, Bulla novae monitionis et requisitionis poenalis praelatorum, \& aliorum vocem in Concilio habentium ([Rome: Antonio Blado, 1545]).

USTC 856127

Statuta, sive constitutiones civitatis Setiae (Rome: Antonio Blado, 1547).

USTC $85255^{8}$

Statuta, sive constitutiones civitatis Reatae (Rome: Antonio Blado, 1549).

USTC $848692-848693$

Leo X, Clement VII, Paul III and Pius IV, Bulla erectionis collegii dominorum militum sancti Petri de Urbe (Rome: [Heirs of] Antonio Blado, [1561]). 